DOI: $10.4274 /$ tpa.46.66

\title{
Lafora hastalığ: ilerleyici bir miyoklonik epilepsi
}

Lafora disease: a progressive myoclonic epilepsy

\author{
Olcay Ünver, Cüyan Demirkesen*, Serap Uysal \\ istanbul Üniversitesi Cerrahpaşa Tıp Fakültesi, Çocuk Nöroloji Bilim Dall, İstanbul, Türkiye \\ *istanbul Üniversitesi Cerrahpaşa Tıp Fakültesi, Patoloji Bilim Dalı, İstanbul, Türkiye
}

\section{Özet}

Lafora hastalığı, başlangıçta iyi seyirli epileptik sendromlar ile karıştıılabilen, nöbetler, miyoklonus ve mental yıkımla nitelenen, otozomal çekinik (resesif) geçişli, nadir ilerleyici bir miyoklonik epilepsidir. Bu yazıda tedaviye dirençli nöbetler ve demans nedeniyle başvuran, öncesinde juvenil miyoklonik epilepsi tanısı alarak takip edilmiş, kliniğimizde cilt biyopsisinde Lafora cisimcikleri gösterilmesi üzerine Lafora hastalığı tanısı alan 17 yaşında bir olgu nadir görülmesi ve diğer iyi seyirli miyoklonik epilepsilerle karışabilmesi nedeniyle sunulmuştur. (Türk Ped Arş 2011; 46: 168-70)

Anahtar sözcükler: Lafora hastalığı, miyoklonus, progresif miyoklonik epilepsi

\section{Summary}

Lafora disease is a rare autosomal recessive progressive myoclonic epilepsy characterized by seizures, myoclonus and progressive cognitive decline. At the beginning of the symptoms the disease may be misdiagnosed as benign epileptic syndromes. Herein we present a 17-year-old girl followed with juvenile myoclonic epilepsy who was later admitted to our clinic with refractory seizures and dementia. A skin biopsy showed Lafora bodies and the diagnosis of Lafora disease was made. (Turk Arch Ped 2011; 46: 168-70)

Key words: Lafora disease, myoclonus, progressive myoclonic epilepsy

\section{Giriş}

İlerleyici miyoklonik epilepsiler (PME) nadir görülen, genetik kökenli, semptomatik yaygın epilepsi grubudur. Klinikte uyarana duyarlı miyoklonik nöbetler, tonik klonik nöbetler, serebellar bulgular, mental yıkım başta olmak üzere ilerleyici nörolojik kötüleşme ile seyreder $(1,2)$. Başlangıç yaşı sıklıkla çocukluk ve ergenlik dönemine rastlamaktadır. Tüm epilepsilerin \%1'inden azını oluştururlar (3). $\mathrm{Bu}$ grup epilepsilerden olan Lafora hastalığı, Lafora ve Glueck (1) tarafından 1911 yılında tanımlanmıştır. Epilepsi, miyokloni, demans ve çeşitli dokularda Lafora cisimciklerinin varlığıyla nitelenen otozomal çekinik geçişli, nadir görülen bir hastalıktır $(1,4)$. Tüm dünyada görülebilmektedir; ancak en sık Akdeniz ülkelerinde ve Kanada'da rastlanmaktadır (1). Bu yazıda tedaviye dirençli nöbetler ve mental yıkım ile başvuran ve Lafora hastalığı tanısı alan bir olgu sunulmuştur.

\section{Olgu sunumu}

On yedi yaşında kız hasta nöbet geçirme, yürürken düşme, unutkanlık yakınmalarıyla kliniğimize başvurdu. Öyküsünden ilk kez 10 yaşında ateşliyken yaygın tonik klonik nöbet geçirdiği; bir yıl sonra ateşli bir dönemde nöbetinin tekrarladığı ve sonrasında yılda 3-4 kez olmak üzere

Yazışma Adresi/Address for Correspondence: Dr. Olcay Ünver, İstanbul Üniversitesi Cerrahpaşa Tıp Fakültesi, Çocuk Nöroloji Bilim Dalı, İstanbul E-posta: olcaymd@hotmail.com Geliş Tarihi/Received: 19.10.2009 Kabul Tarihi/Accepted: 23.03.2010

Türk Pediatri Arşivi Dergisi, Galenos Yayınevi tarafindan basılımıştı. / Turkish Archives of Pediatrics, published by Galenos Publishing 
ateşsiz dönemlerde de nöbet geçirdiği öğrenildi. On dört yaşında elektroansefagrofi (EEG)'de yaygın çoklu diken dalga kompleksleri saptanması üzerine juvenil myoklonik epilepsi tanısı konarak öncelikle valproik asit başlandığı, ardından nöbetlerinin sürmesi nedeniyle değișik antiepileptik ilaçların eklendiği ve bize bașvurusunda halen valproik asit+levetirasetam kullanmakta olduğu öğrenildi. Ailesinden ilaç tedavisine rağmen nöbetlerinin azalmadığı, kol ve bacaklarda silkinme şeklinde nöbetlerinin olduğu ve okul başarısında düşüklük nedeniyle okulu bırakmak zorunda kaldığı öğrenildi. Hasta, dirençli nöbetleri ve bilişsel işlevlerinde bozulma nedeniyle ileri tetkik için yatırıldı. Anne ve babası üçüncü dereceden akraba olan hasta, ailenin üçüncü çocuğu idi. Bir kardeşin altı aylık iken bilinmeyen bir nedenle kaybedildiği, diğer iki kardeşin sağ ve sağ|ıklı olduğu öğrenildi. Dört yaşındaki erkek kardeşinde bir kez febril konvülziyon hikayesi mevcuttu. Soygeçmişinde başka özellik yoktu.

Fizik muayenesinde boy ve tartısı normal persantiller içindeydi. Bilinci açıkdı, iletişim kurabiliyordu. Bilişsel işlevlerinde bozulma mevcuttu. Duygusal değişkenliği dikkat çekmekteydi. Kas gücü, kraniyal sinir muayenesi, refleksler normaldi. Hafif derecede dizartrisi ve tremoru mevcuttu. Duyu kusuru yoktu.

Laboratuvar tetkiklerinde tam kan sayımı, karaciğer ve böbrek işlev testleri, elektrolitler, kan laktat, amonyak, vitamin B12 düzeyi normaldi. Kan ve idrar aminoasitleri, idrar organik asitlerinde bir özellik yoktu. Kan valproik asit düzeyi $122,3 \mathrm{mc} / \mathrm{ml}$ (50-100) idi. Göz dibi muayenesi normaldi. Elektroansefagrafisinde temporopariyetooksipital bölgelerde paroksismal özellik gösteren yavaş dalga aktivitesi üzerinde yer yer yaygın ve hızlı diken-dalga deşarjları görüldü (Şekil1). Nöropsikolojik testlerden Cattel

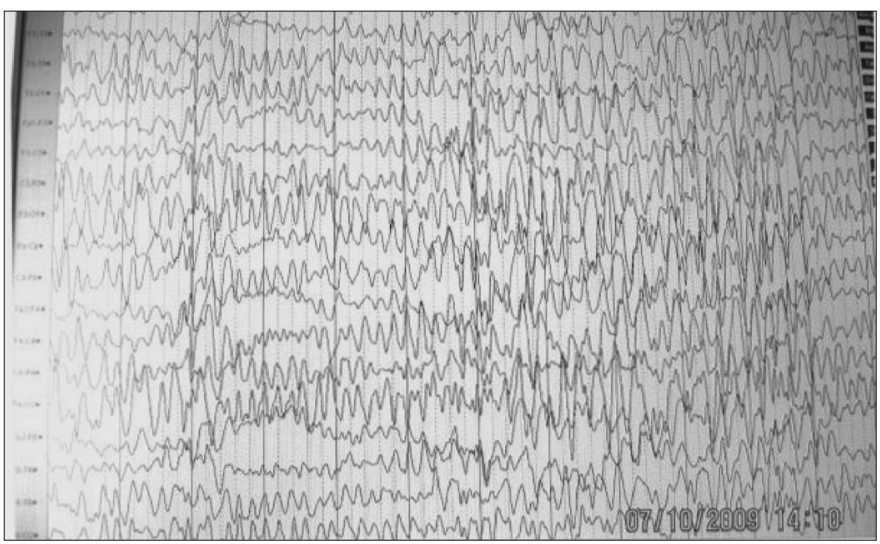

Şekil 1. Temporopariyetooksipital bölgelerde paroksizmal özellik gösteren yavaş dalga aktivitesi üzerinde yer yer yaygın ve hızlı diken-dalga deşarjları testine göre; IQ'si 50 olarak saptandı. Kraniyal manyetik rezonans görüntülemede ve pozitron emisyon tomografisinde bir özellik saptanmadı. Ilerleyici miyoklonik epilepsilerden Lafora hastalığı düşünülen hastaya koltukaltı apokrin ter bezlerinden derin cilt biyopsisi yapıldı. Cilt biyopsisi sonucunda apokrin glandlar içinde diyastaza dirençli PAS pozitifliği gösteren Lafora cisimciklerinin varlığı gösterilerek hastaya Lafora hastalığı tanısı kondu (Şekil 2). Valproik asit ilaç dozu düzenlendi; dört yaşında febril konvülziyon geçiren EEG'si normal olan kardeşine de cilt biyopsisi yapılması planlandı. İzleminde nöbeti olmayan hasta kontrole gelmek üzere taburcu edildi.

\section{Tartıșma}

Illk kez 1911 yılında tanımlanan (Online Mendelian Inheritance in Man $\left[\mathrm{OMIM}^{\circledR}\right]$ 254780) Lafora hastalığı, nöbetler, miyoklonus ve demans ile nitelenen otozomal çekinik geçişli ilerleyici bir miyoklonik epilepsidir $(1,5,6)$. Bașlangıç yaşı 10 ile 19 arasında değișir (4). Genellikle yaygın tonik klonik konvülziyonlar ve kısmi nöbetler (görsel halüsinasyon ve skotoma) ile başlar, takiben asimetrik miyoklonus, demans, ataksi gelişir (3). Başlangıçta diğer iyi seyirli miyoklonus epilepsilerinden ayırmak güçtür. Özellikle başlangıç yaşı benzerliği, miyoklonus ve ışığa duyarlı nöbetlerin varlığı nedeniyle daha sık görülen iyi seyirli juvenil miyoklonik epilepsi ile karışır $(2,5,7)$. Ancak EEG'de yavaş zemin aktivitesi görülmesi, antiepileptik ilaçlarla tedaviye direnç, diğer nöbet tiplerinin (görsel, kompleks kısmi veya absans gibi) varlığı, bilişsel bozulma ve bulguların hızlı ilerlemesi ilerleyici miyoklonik epilepsi şüphesini doğurur $(1,3,5)$. Ergenlerde bu bulgular Lafora hastalı̆ı̆ın düşündürtür. Bulgular, takip eden yıllarda hareket veya dış



Sekil 2. Apokrin bezler içinde diyastaza dirençli PAS pozitifliği gösteren Lafora cisimcikleri 
uyarılar (Işık, ses, dokunma) ile tetiklenen miyoklonus, dirençli nöbetler, psikoz, ataksi, dizartri ve demansa ilerler. Seyir kötüdür, genellikle 10 yıl içinde ölümle sonlanır (5).

Lafora hastalığının karbonhidrat metabolizmasında bir bozukluğa bağlı olarak geliştiği düşünülmektedir. Hastalığa özgü Lafora cisimcikleri, poliglükozan olarak adlandırılan anormal yapıdaki glikojenden oluşmuş hücre içi cisimciklerdir. Bu cisimcikleri nöronlar ve kalp, karaciğer, kas, deri gibi başka dokularda depolanırlar (5). Lafora hastalığı otozomal çekinik geçişlidir. Hastalıktan 6q23-25 bölgesine yerleşik EPM2A ve 6p22-32 bölgesine yerleşik EPM2B genlerindeki mutasyonlar sorumludur $(3,8)$. EPM2A geni tirozin fosfataz (Laforin proteini) ve EPM2B geni malin proteinini kodlar; her iki protein de tirozin fosfataz aktivitesi ile hücreden polisakkaritleri uzaklaştırır $(3,5)$. Biyopsi ile Lafora cisimciklerinin görülmesi tanısaldır (9). Lafora cisimcikleri ekrin ve apokrin duktuslarda görüldüğünden koltuk altı biyopsi için en uygun yerdir (10). Uygulanacak deri biyopsisi ekrin ve apokrin ter bezlerini içerecek şekilde yapılmalıdır. Örnekleme hatalarına bağlı yanlış negatif sonuçlarla sıklıkla karşılaşılmaktadır $(2,11,12)$. Genetik tanı mümkündür. Türk olgularda her iki gen de mutasyona uğramış olarak bulunmuştur (3).

Lafora hastalığının kesin tedavisi yoktur. Miyoklonus için erken dönemlerde valproat, fenobarbital, benzodiyazepinler, pirasetam, levetirasetam ve zonisamidin birlikte kullanımlarında fayda görülebilir. Miyoklonusun kötüleşmesini önlemek için karbamezepin, fenitoin, gabapentin, pregabalin ve lamotrijinden kaçınılmalıdır. Gelecekte gen tedavisi bir seçenek olacaktır $(2,5)$. Günümüzde EPM2A geni ile ilgili çalışmalar ilerleme göstermiştir (3).

Ülkemizde bugünkü koşullarda daha çok genetik öncesi klinik ve laboratuvar tanıya yönelik çalışmalar sürdürülebilmektedir. Toplumlar arası hastalık genlerindeki farklılıklar göz önüne alındığında toplumumuzda epilepsi genetiği profilini saptamak gelecekte uygulanabilir tedavi yöntemlerine de öncülük etmesi açısından da önem taşımaktadır (3).

Sonuç olarak; bilişsel kötüleşme ve EEG'de zemin ritmi yavaşlamasının eşlik ettiği juvenil miyoklonik epilepsi tanısı almış olgular, ilerleyici miyoklonik epilepsiler ve Lafora hastalığı açısından yeniden değerlendirilmelidir.

Çıkar çatışması: Bildirilmedi.

\section{Kaynaklar}

1. Baykal BB, Özemir ZA. Progresif miyoklonik epilepsiler. İçinde: İbrahim Bora, Naz Yeni, Candan Gürses, (yazarlar). Epilepsi. İstanbul: Nobel tıp kitabevleri, 2008: 271-90.

2. Panayiotopoulos CP. A clinical guide to epileptic syndromes and their treatment. Second edition. Springer, Oxfordshire, 2007: 475-82.

3. Baykal B. Progresif miyoklonik hastalıklar- Lafora hastalığı. Epilepsi 2008; 14: 17-51.

4. Kaplan KJ, Nelson BL. Pathologic quiz case myoclonic epilepsy and cognitive decline in a 19-year old man. Arch Pathol Lab Med 2003; 127: 231-2.

5. Striano P, Zara F, Turnbull J, et al. Typical progression of myoclonic epilepsy of the Lafora type. Nature clinical practice neurology $2008 ; 4: 106-11$.

6. Lafora GR, Glueck B. Contribution to the histopathology of the myoclonic epilepsies (German). Z Gesamte Neurol Psychiatr 1911; $6: 1-14$

7. Güler A, Gökçay A, Kandiloğlu G, ÖE Özbay, H Karasoy. Juvenil miyoklonik epilepsi kliniği ile prezente olan lafora hastalığı. Ege Tıp Dergisi 2009; 48: 131-4.

8. Jansen AC, Andermann E. Progressive myoclonus epilepsy, Lafora type. Gene reviews NCBI Bookshelf 13.05.2009.

9. Carpenter S, Karpati G. Sweat gland duct cells in Lafora disease diagnosis by skin biopsy. Neurology 1981; 31: 1564-8.

10. Karimipour D, Lowe L, Blaivas M, Sachs D, Johnson TM. Lafora disease: diagnosis by skin biopsy. J Am Acad Dermatol 1999; 41: 709-12.

11. Franceshetti S, Gambardella A, Canafoglia L, et al. Clinical and genetic findings in 26 Italian patients with Lafora Disease. Epilepsia 2006 ; 47 : 640-3.

12. Turnbull J, Kumar S, Muralitharan S, et al. Lafora progressive myoclonus epilepsy: Disease course homogeneity in a genetic isolate. J Child Neurol 2008; 23: 240-2. 